\title{
The Trial of Fausto Sozzini in Siena
}

\begin{abstract}
I
In his published over three decades ago paper based on manuscripts kept in Archivio di Stato in Florence, Valerio Marchetti discussed, amongst other things, a campaign aimed by Catholic Counter-Reformation against Fausto Sozzini, who resided in Poland since 1579. ${ }^{1}$ The main aim of the campaign was to deprive Sozzini of the earnings from his property in Siena. Marchetti couldn't have known at that time that records of a lawsuit in absentia brought against Sozzini in Siena in 1558-91 have been preserved. The documents, while bringing no revelation, shed nevertheless a new light on the relationship between Sozzini and his abandoned homeland, on the attitude of the Sienese society toward him, and - last but not least - on the tactics and strategy applied by the Inquisition, not to mention their illuminating aspect, since the files themselves contain a lot of new information.

The records included in the archive of the Holy Office in Siena are almost completely preserved, but remained inaccessible and forgotten until recently. After the Inquisition tribunals had been closed down in Tuscany in 1872, the records were stored in the archiepiscopal curia in Siena, and then transferred in 1911 to the archive of the Holy Office in Rome. ${ }^{2}$ The records were mentioned for the first time - at least to my knowledge - in
\end{abstract}

1 V. Marchetti, 'Do biografii Fausta Socyna (Nowe listy do wielkich książąt Toskanii z lat 1576-1586)', Odrodzenie i Reformacja w Polsce, 14, 1969, pp. 151-63.

2 A. Cifres, 'L'Archivio storico della Congregazione per la Dottrina della Fede', in L'apertura degli archivi del Sant'Uffizio Romano, Rome, 1998, p. 83. 
1984 by Sergio M. Pagano, ${ }^{3}$ and became accessible for scholars in 1998 , when the Roman archive of the Holy Office (today's Congregation for the Doctrine of the Faith) has been opened. In November 1998, after several decades of futile endeavours, I could finally access the archive. I tried to find the file of Fausto Sozzini when preparing the entry devoted to him for the Polish Biographical Dictionary. ${ }^{4}$ I did not succeed, however, because I had not enough time during my stay in Rome. Fortunately, I met Dr. Oscar Di Simplicio who organised the archive and kindly offered me his assistance. He didn't keep me waiting long, and as early as on 11 February 1999, the reliable Di Simplicio informed me - I would like to express hereby my sincerest gratitude towards him for this and other favours ${ }^{5}-$ that the Sozzini records have been found. Thus I had to visit Rome again in December 1999, to read - not without emotion - the records. ${ }^{6}$ I took also the opportunity to refer to other sources kept in Rome, which enabled me to verify and to qualify some trains and information.

I am fully aware, however, that I had again not enough time for an in-depth research. This is why some questions have not been completely explained, while others are only signalled and need further research. The latter concerns, above all, the complex issue of Sozzini's legacy, claimed by the Inquisition in Siena and simultaneously by his family, that is the sons of his uncle Celso Sozzini.

II

The trial of Fausto Sozzini in Siena was a closure - though a symbolic one only - of a heretical chapter in the history of his family in Italy. The first full-scale attack of the Inquisition on the family ${ }^{7}$ in 1560 was followed by other repressions. Repressive measures afflicted Celso Socini (ob. 1570) who was being closely watched by the Holy Office, ${ }^{8}$ as well

3 I documenti del processi di Galileo Galilei, ed. by S. M. Pagano, Vatican, 1984, p. 43.

4 L. Szczucki, 'Socyn Faust Paweł', in Polski Stownik Biograficzny, vol. 39, no. 4 (163), Cracow, 2000, pp. 631-36.

5 I am deeply grateful also to Dr. Michaela Valente and Professors: Silvano Cavazza, Andrea Del Col, and John Tedeschi for their help.

6 Rome, Archivio della Congregazione per la Dottrina della Fede (hereafter, ACDF), Siena, Processi, file 16, 11. 376-431.

7 V. Marchetti, Gruppi ereticali senesi del Cinquecento, Florence, 1975, pp. 211-44.

8 G. Dall'Olio, Eretici e inquisitori nella Bologna del Cinquecento, Bologna, 1999, pp. $273-74$. 
as his son Dario Sozzini, who, between 1568 and 1574, was arrested, imprisoned and kept under surveillance in Bologna and Rome. ${ }^{9}$ The repressions befell also Cornelio Sozzini, who was continually persecuted and died shortly - as it seems - after his last trial in Rome. ${ }^{10}$ Only Camillo Sozzini ${ }^{11}$ - Fausto's uncle, his peer and a person ideologically closest to him - avoided the Inquisition's persecutions, having emigrated to Switzerland. However, as a result of a conflict with orthodox Calvinists, he moved to Lyon where he barely escaped death in a slaughter of Huguenots after the St. Bartholomew's Day. There, he has been saved by an influential compatriot, converted to Catholicism and sought to return safely to Italy. Camillo died probably around $1575 .{ }^{12}$

9 ACDF, S.O., St.St., EE 1 a., 1l. 297, 438, 487, 504, 509v, 514, 527; S.O. Decreta 1567-1571, 1. 155v; Decreta 1571-1574, 1l. 93v, 116, 118v, 130, 131.

10 A. Stella, Dall'anabattismo al socinianesimo nel Cinquecento veneto. Ricerche storiche, Padua, 1967, pp. 146-58, 170. Valuable information concerning troubles caused by the Inquisition to the Sozzini family in general, and Cornelio in particular, can be found in the records of interrogation (among the witnesses there were members of the family, as well as its friends and acquaintances) in the Cornelio's trial in Siena in 1581 (ACDF, Siena, Processi, file 15, 11. 441-47, 454-73r).

11 The story of Camillo's survival and conversion in Lyon was related to the inquisitors on 18 January 1581 by Girolamo Bargagli, a former Fausto's friend, who was questioned during the trial of Cornelio Sozzini. The story has been confirmed - although in a less detailed form - by Alessandro Sozzini, son of Girolamo (ACDF, Siena, faldone 15). ACDF, S.O., St.St., HH 2d-1, 1. 239r, contains Camillo's petition to cardinals great inquisitors (without date, but written doubtlessly in 1572/73), which is quoted hereby in extenso: 'Illustrissimi et Reverendissimi Patroni semper Osservandissimi, Camillo di Messer Mariano Sozzini, humilissimo servitore delle Vostre Signorie Illustrissime et Reverendissime, essendo tornato con l'animo et con l'opere alia obbedientia della sancta Chiesa Catholica et Apostolica Romana le supplica humilmente che si degnino di riconoscerlo et di riceverlo per vero penitente, si come per tale e stato riconosciuto et ricevuto dalli Ministri deputati in Lione perció dal Sancto Officio, et di perdonarli pienamente et assolutamente ogni suo passato errore, rimettendolo nel suo primiero stato, come se mai non havesse disubbidito, non ostante che prima in Italia per alcun tempo habbi havute opinioni et fatte opere contrarie alii decreti et precetti di Sancta Chiesa et poi sia stato contumace publicamente scomunicato et sia vissuto parte alii confini di Italia et parte fuor d'Italia dodici anni continui in cosi fatte perverse opere et opinioni che ne terrà alle Signorie Vostre Illustrissime et Reverendissime obligo perpetuo et singulare, pregando del continuo la Divina Maestà per ogni loro maggiore felicita et grandezza'. It is not known, however, whether the petition met with any response of the Holy Office.

12 V. Marchetti, 'Documenti sul patrimonio di Fausto Sozzini', Critica storica, 7, 1968, p. 541, note 4; cf. also: ibid., p. 549. 
Fausto Sozzini, having left Italy in 1575 and since 1579 residing in Poland, was the only member of his family who remained out of reach for the Holy Office. He might, however, have been afraid that the powerful institution would sequester his Italian property, which was managed by his brother-in-law Cornelio Marsili in Siena. In his above-mentioned paper, Valerio Marchetti described in detail the problems encountered by Fausto in the first half of 1580's when the efforts of the nuncio A. Bolognetti resulted in withholding of his incomes. It was only through the protection of the Grand Duke Francesco de' Medici and his wife Bianca Capello that the sanction was lifted. ${ }^{13}$ The unexpected death of both Sozzini's protectors in October 1578 and assuming of the Grand Dukedom by the cardinal Ferdinando de' Medici has created new possibilities for the Sienese Inquisition. It took eagerly the opportunity, as it appears from the records of Fausto's trial.

On 1 June 1558, A. Baccellieri, the prosecutor of the Holy Office in Siena, put forward a motion to take legal proceedings against Fausto Sozzini and to pronounce him 'esse vere et formaliter haereticum impenitentem et pertinacem', who thus should be subject to appropriate punishment, censorship and confiscation of property. The motion was backed with following charges:

1. When leaving Siena years ago, Sozzini had 'a bad opinion when it comes to faith'.

2. After having left Siena, Sozzini 'in public and privately, propagated and obstinately defended heretical theses in many and various places etc.'

3. 'The said Fausto, when attending Masses and services, criticised and ridiculed them by uttering inappropriate and improper words, and also by committing other heretical deeds etc.'

4. 'The said Fausto, so as to become more confirmed and developed in his perverse opinion, left Italy and the Christendom and settled in Germany and Cracow [nelle parti di Germania et Crecovia] among Lutherans. When living among the latter, he established new sects, and particularly his own one, that he called Sienese or by a similar name'.

5. When residing in the above-mentioned countries, married 'not a Catholic, but a Lutheran woman, and lived as other Lutherans used to do'.

6. All these matters are known from 'pubblica voce et fama'.

13 Marchetti, 'Do biografii...', op. cit., pp. 157-59. 
It follows from the above charges that the Sienese Inquisition had access to detailed information about Fausto Sozzini. It is not surprising, considering the role of his family in the heretical movement in Siena and - on the other hand - the information passed on to Ascanio Piccolomini, the coadjutor bishop of Siena, by the papal nuncio to Poland Alberto Bolognetti, in 1584 (this question will be addressed in due course). It is noteworthy that, when examining witnesses, the inquisitors paid almost no attention to anti-church activity of Sozzini in Siena. Supposedly, they appreciated the fact that the body of evidence - related, as a matter of fact, to distant times - was not particularly convincing.

The first witness to be examined for the prosecution - on 8 June 1588 - was Fulvio Bulgarini, actually a descendant of a family related to Sozzini. As it seems, Bulgarini fell victim to his own garrulousness, which the inquisitor has heard about.

The examination report shows clearly that the witness was embarrassed and reluctant to give more detailed explanations. According to his own words, Bulgarini received information about Sozzini in Prague in 1587/88, from a Florentine. It was, however, a knowledge certainly well known to the Inquisition already: 'he married and he had a daughter'. The Florentine, whom Bulgarini couldn't identify in a more detailed way (or was unwilling to do it), suggested that Bulgarini should intervene with a Sozzini's tenant in Siena concerning all the payments due. Bulgarini claimed that he did not even want to discuss the subject: 'I answered - let's talk about other things, because about this I do not want to speak'. This proves that - contrary to his initial claims - Bulgarini's acquaintance with the Florentine was much closer than he was ready to admit. Bulgarini was not interested in incriminating Sozzini, as the following exchange indicates:

\footnotetext{
When asked whether he has heard from anyone in the said German lands that Fausto invented a new heresy and, as a heresiarch, had initially numerous followers who later abandoned him - he answered: Nobody talked with me about that Fausto, save for the said Florentine. I don't remember what he said at that time, except for what I testified already, and namely that he considered Fausto as a very noble mind.
}

Another witness, Roberto de' Vecchi, reported to the tribunal on 30 June 1588 , in fear of being excommunicated. During an evening stroll with 
family and friends, he heard from Marcantonio Campani 'that Rutilio Marsili of Siena went to Lutherans, and that his uncle is also there'. The name of the uncle was unknown to the witness.

Because of that testimony, also Marcantonio Campani has been questioned, on 26 August 1588. He explained that Niccolò Bordoni admitted in a conversation to having lent money to Rutilio Marsili. Rutilio needed the money, because he intended to visit 'Frastagliato [a name given to Fausto Sozzini in the Sienese Accademia degli Intronati], his uncle'. Pressed by the inquisitor, who inquired whether he heard that Sozzini 'stayed and still stays among Lutherans', he remembered that, when visiting a bookseller named Marcantonio twelve or fifteen years earlier, he heard of Fausto Sozzini having written a letter of condolence to count Antonio Bresciano because of the death of his friend. The letter was reportedly sent 'dalle parti di luterani'. While Campani wasn't willing to open up - despite of the inquisitor's admonitions, the next witness, Orazio Spanocchi (also of Sienese origin), who was questioned by the Bolognese tribunal on 16 September 1588, had much more to say. Orazio Spanocchi, a jurist and a former secretary of the papal nuncio to Poland (1581-85) A. Bolognetti, gave a detailed evidence of his - official in a sense - relations with heretics. This is what he said about his contacts with Fausto Sozzini:

I spoke two or three times with that Fausto of the Sozzini family in Cracow; he told me that he does not adhere to the Catholic religion, which he calls papist, whereas from them [that is, heretics] I learned that the said Fausto writes and publishes books defending the sect of Samosata. I wrote a letter to my father in Siena, describing my travel and cities where we stayed. Many issues were raised in the letter, among them a tribulation which I experienced in Cracow because of the fact that a Sienese resides there, who is commonly regarded as a heresiarch. I didn't mention his name, but it's the said Fausto that I meant. [...] I wrote the letter shortly after having arrived to Cracow, before even I met him [that is, Fausto]. That Fausto has been informed about my letter and when I returned to Cracow two years later, he told me about it himself, with much grudge and wailing. Then, in Lithuania, I asked the cardinal Bolognetti to write about that matter to Siena, which he did. After my return from Poland, I related it to many persons, and particularly to monsignor Ascanio Piccolomini, [L1] who is the archbishop of Siena today, and then was an auxiliary bishop, 
what was said about Fausto: that he is an heresiarch, that he renewed the Arian sect and that he lectures, promoting heretic doctrines. And when I first spoke with that Fausto, he complained about my letter to Siena, being convinced that it was because of that letter that two tenants of his estate - Alessandro and Cornelio Marsili - have been prohibited from paying him. I saw a letter, concerning that matter, from one of the two tenants who used to send him money through a bank. Moreover, I saw also letters written by Fausto himself, and sent by the archbishop of Siena to the cardinal Bolognetti, on money that was paid to him in Cracow. ${ }^{14}$

In the context of the above-mentioned letter of A. Bolognetti to A. Piccolomini, dated 8 April 1584 and included in the record of the trial, ${ }^{15}$ it is evident that Spanocchio played an important role in the campaign against Sozzini. Bolognetti did not mention his name, but it appears clearly from the contents of the letter, compared to the testimony of Spanocchio, that it was the latter - the nuncio's secretary of Sienese origin, from a family having a close friendship with Sozzini - who disclosed to him in Vilnius, reportedly under pressure from his confessor:

how does Fausto Sozzini receive money from signor Cornelio Marsili in Siena, and that he knows about it, because he saw a letter written to Sozzini by signor Marsili himself, who apologised for a delay in sending the money [...]. He wrote, moreover, that he made some efforts to persuade a relative of that Sozzini - a nun known as sister Eustochia, ${ }^{16}$ whom he considered a possessor of

14 Towards the end of the interrogation, Spanocchi said: 'Altro non m'occore per adesso che io mi ricorda, se non che questo Fausto e dimandato la in Cracovia angelo et il gran teologo toscano', thus confirming one of the charges. It may be supposed that it was Spanocchi who quoted during his conversation with Piccolomini those praises of Sozzini that circulated among heretics in Cracow. It should be mentioned also that A. Bolognetti wrote to the Roman Inquisition in his memorial concerning Roman heretics in Cracow $(23$ April 1583) that Fausto 'vien chiamato angelo mandato da Dio' (Alberti Bolognetti nuntii apostolici in Polonia Epistolae et acta 1581-1585, Part 2: 1583, ed. by E. Kuntze, Cracow, 1935 (Monumenta Poloniae Vaticana, 6), p. 257. 15 The copy is provided with an annotation: 'Illustrissimus et Reverendissimus Archiepiscopus Senensis has litteras praesentari fecit huic Sancto Tribunali die 21 Januarii 1590, quarum litterarum fuit praescripta copia'.

16 The quoted above records of examination in Siena in 1581 concerning Cornelio Sozzini mention also 'suor Eustochia' (26 January 1581) 'in secolo Izabetta Attoli bolognese', a sister of Cornelio Sozzini's wife Francesca, who was brought up in his house. 
wealth - to name Sozzini her heir, although other [relatives] strongly dissuaded her from such a decision.

Evidently, Bolognetti counted on Piccolomini's intervention: 'and because so important matter is concerned as the honour of the God and the salvation of a city as noble and important as Siena, lying in the very centre of Italy, I commend this matter wholeheartedly to the piety and prudence of Your Eminence'.

In his answer (dated 26 August 1584), which has been known for a long time, ${ }^{17}$ Piccolomini stressed the orthodoxy and good will of Cornelio Marsili, who reportedly didn't know the religious views of his brother-in-law and who handed over his letters, without unsealing them, to the bishop (these were then sent to the nuncio). It is well known that Piccolomini was once friendly with the Sozzini family and that in 1562 he supported Celso Sozzini in his efforts to get Cornelio Sozzini released from the Roman Inquisition's prison. ${ }^{18}$

Late in September 1588, the examination of witnesses intensified. On 26 September testified the above-mentioned Niccolò Bordoni. Sparing in words and responding evasively, he admitted to having borrowed money to Rutilio Marsili, but he evidently tried to evade indicating the purpose of the loan. It was only the inquisitor's reprimand that persuaded him to become more candid. He confessed to having heard that Rutilio planned to visit 'his uncle of the Sozzini family in a distant country'; moreover, he offered to show a letter written by Rutilio (the letter, sent on 19 June 1588 from Vienna, was then included in the records $s^{19}$ ). When asked about the denomination of the said uncle, he denied any knowledge, and concerning opinions on him, he responded: 'I have heard that he is an outstanding man [valenthuomo] and as such regarded in those

17 Alberti Bolognetti..., op. cit., Part 3, no. 2: M. Junio 1584-Maio 1585, appendix M. Jan. 1584 - Febr. 1585, ed. by E. Kuntze, Cracow, 1950 (Monumenta Poloniae Vaticana, 7), pp. 418-19.

18 Celso Sozzini's wife Lucrezia testified on 26 January 1591: 'Io intesi ragionare che messer Celso per mezzo de Monsignor Arcivescovo procurava remissione et alleviatione de penitenze per Messer Cornelio essendo ammalato de gravi infermita [...]' (ACDF, Siena, Processi, file 15, 1. 469).

19 'Pregovi a taciere il mio ritorno', concluded Rutilio his letter. It is noteworthy that Fausto Sozzini tried to stay in touch with his nephews, Orazio and Rutilio Marsili. Cf. Marchetti, 'Documenti...', op. cit., p. 547. 
countries. He has no desire to earn his living as a merchant, but if he decided to take up this trade, he would amass a fortune'. Bordoni did not remember - which seems to have been almost customary for citizens of Siena under interrogation - the author of those words. This, as it seems, confirmed the interrogators in their belief, that they were dealing with a suspicious character. He was ordered to keep secret, but also prohibited from leaving the seat of the Holy Office without permission of the inquisitor. Having evidently got scared, the previously reticent witness requested another examination, during which he confessed that Sozzini, Rutilio Marsili's uncle, resided in Cracow, Poland, where he had 'a bad reputation as a Christian and Catholic'. Bordoni reported to have learned 'in my workshop, but I don't remember whence, that the said Fausto is not a very good Catholic and he should be burnt at the stake, because his sins deserve such a punishment'.

The next witness, Marcantonio Ferreri (questioned on 26 September), did not contribute much to the case, basically only confirming the testimony of Marcantonio Campani; the same concerns the examination of Adriano Cinuzzi on 27 September. Cinuzzi explained that the letter sent by Rutilio Marsili, who asked for a loan, was addressed to his late brother Fabbio, with whom Rutilio had friendly relations. Adriano Cinuzzi guessed, however, that Rutilio's travel had much to do with the property of Faust Sozzini, leased to Cornelio Marsili - Rutilio's father. The witness provided no further explanations, reportedly due to lack of knowledge.

On 29 September 1588, Rutilio Marsili was finally examined. The dry record betrays, however, dilemmas of the young man who - faced with embarrassing questions - tried to evade with non-committal or vague responses.

Already preliminary Rutilio's explanations herald further problems for him to face: 'I went to Cracow to meet him [that is, Fausto Sozzini], because it was thirteen years that I haven't seen my uncle, the own brother of my mother. I thought, however, that he is a Catholic'.

The next query - about 'circumstances which he saw and learned, and which indicate that he [Fausto] is not a Catholic' - clearly embarrassed the witness: 'I never found personally that he is not a Catholic. However, two Florentine merchants, whose names I do not know, told me that he is not a fervent Catholic'. 
Next, Rutilio confessed that he remained with Sozzini twenty-five days, because he didn't know anybody in Cracow and he didn't understand Polish either. When asked about Fausto's wife (Elżbieta, of the Morsztyn Family), he stated only that she died, but he doesn't know her name. He added, however - without having been asked! - that '[Sozzini's] father-in-law is a fervent Catholic'. Presumably he hoped that the inquisitors cannot know such a minute detail.

After those initial questions, there came next ones - extremely dangerous for the witness: whether he saw any images of the apostles or other saints of the Catholic Church in his uncle's house. The question was not ungrounded, because already in 1562 the inquisitors who carried out a search of Sozzini's residence in Scopeto noticed the lack of any holy images therein. ${ }^{20}$ Embarrassed Rutilio found no other answer than: 'I haven't delivered them, thus I don't know if there are any'. When asked whether such images were in his own lodgings, he claimed not to remember, adding immediately: 'But every morning I attended a Mass together with my servant, and I know very well that Fausto had a servant who sometimes attended Masses together with me'. He had, however, to admit that he never saw his uncle attending a Mass. He denied also categorically that he ever discussed with him (Fausto) the opinion of the two merchants. When asked, if Fausto Sozzini gave any lectures, he claimed to have heard different opinions in this respect. The inquisitors were not satisfied with this answer. To the next question: 'whether he [Fausto] lectured professionally on the Holy Scripture' - Rutilio replied rather oddly: 'This I do not know, for I'm not educated, but I've heard that he is an outstanding man [valenthuomo]'. Only the apparently innocent question concerning the uncle's attire was evaded by Rutilio without any difficulty: 'he wore a long black robe because his wife died, and long robes are worn in that country'. Finally, asked if Fausto ever visited a Catholic church together with him, Rutilio denied, adding, however: 'he said once to me: go, hear a sermon'.

Naturally, such testimony was not satisfactory to Rutilio's interrogators, who found it improbable that he was ignorant of his uncle's confession or that he never talked with him about it. In vain assured the young man that all his conversations with Sozzini concerned only the lease of his estates - the inquisitor placed him under house arrest.

20 Idem, Gruppi..., op. cit., p. 241. 
When this happened, the next witness (Rutilio's father Cornelio Marsili, who testified on the same day) became certainly aware that his son run into a serious danger. After Cornelio described his relationships with his brother-in-law (the latter hasn't written to him since three months), the inquisitor asked him about Fausto's religious sentiments. In contrast to his son, Cornelio Marsili offered detailed explanations immediately:

\begin{abstract}
What do you want me to know? He wrote to me about his marriage and I know from others that he sermonises, lectures and is regarded as a scholar: moreover, the honourable archbishop of Siena told me that he is a heretic and forbade me to write or to send him any money. I complied with this instruction, but as a result of a supplication submitted to the Grand Duke [of Tuscany] it was decided that it is allowed to send him letters and his earnings.
\end{abstract}

The interrogators passed tactfully over the delicate question of the friendly relationships between Francesco de' Medici and Fausto Sozzini, asking only a question about the reputation of the Sozzini family in Siena. The answer was succinct but significant: 'It is said about the Sozzini family that one of them used always to abide among heretics. ${ }^{21}$

On the same day, Rutilio Marsili was examined once more. Presumably briefed by his father, the young man appeared completely resigned. Asked at the beginning of the interrogation whether he has 'a more positive attitude', he promised to answer every question. Then he admitted to having heard already in Siena that his uncle was a heretic, and that he heard the same in Cracow from 'certain merchants by the name of Montelupi'. Rutilio tried to defend himself saying that he left his uncle's house immediately after he became certain in that matter, even though initially he intended to stay in Poland a year or maybe longer. 'As a young man and his nephew', he didn't dare to talk about this with Fausto.

The examination of the prosecution witnesses concluded the first stage of the proceedings. On 1 October 1588, a subpoena of the Holy Office has been displayed on the door of the cathedral and on the San Francesco church, as well as on the house of Cornelio Marsili in Siena. It was demanded from Fausto Sozzini - accused of public and private

21 In the context of the whole trial, Cornelio Marsili seems to have been a loyal and devoted friend of his brother-in-law. I mention this only because Marchetti ('Do biografii..., op. cit., pp. 157-59) tended to regard him with a dose of criticism. 
activity with the use of printed documents, sermons and lectures aimed against the Roman Church and containing tenets and arguments contrary to the Catholic faith - to appear within twenty days before the Holy Office in Siena in order to respond to the charges.

At the same time the inquisitor in Siena informed the congregation of the Holy Office in Rome of the case of Sozzini. It has been noted in the report of the congregation's meeting on 26 October that 'the cardinals great inquisitors - having familiarised themselves with the above-mentioned letter - ordered to continue the trial and to bring about the confiscation of Sozzini's property'.22

The arrival of Fulvio Bulgarini, who was already questioned at an earlier stage of the trial, added variety to the routine legal proceedings (next claims have been filed on 22 October and 12 November 1588). Being certainly aware that other witnesses turned out to be more willing to open up than himself, and probably persuaded by the inquisitors (Bulgarini mentioned two or three interrogations, but only the first one was recorded), he offered additional explanations, 'to ease my conscience'. In fact, he only authorised a question that he heard previously, when he admitted to having concluded from a conversation with a Florentine whom he met in Prague, that 'Frastagliato lives a bad life and they use him as a writer in that country [that is, Poland], perhaps also in others, because he is regarded as an extremely subtle man. He used his subtlety in the defence of those sects that couldn't follow him because of his subtlety'.

It may be supposed that the Florentine in question was a renown Italian heretic Francesco Pucci, who resided at that time in Prague and who knew Fausto Sozzini very well. A few years later, Pucci described in a similar way - though more spitefully - the collaboration between Sozzini and Polish anti-trinitarians. ${ }^{23}$

On 28 November 1588, the prosecutor A. Baccellieri declared an unexpected motion. He applied for Fausto's uncle Camillo to be summoned before the Inquisition tribunal in Siena. In Baccellieri's opinion, 'a rumour has it in that city [that is, Siena] that Camillo, being an infidel and heretic, got down to Poland around twenty years before to live in his own way, after the fashion of heretics'. Thus Baccellieri asked Camillo

22 ACDF, S.O., Decreta 1588, 1. 392v.

23 Cf. F. Pucci, Lettere documenti e testimonianze, ed. by L. Firpo and R. Piattoli, vol. 1, Florence, 1955, p. 151 (Pucci's letter to one of his friends in Prague, 5 January 1593). 
Marsili to be called on to witness, adding that Camillo's earnings were sent to Cracow, to Fausto Sozzini, who in turn transferred them to Camillo. The tribunal did not accept that motion, which was based on outdated and inaccurate information (because Camillo lived in Switzerland and France, but never in Poland), and allowed Marsili to give information relevant in that respect.

On 20 December 1588, Fausto Sozzini was ceremonially excommunicated because of his failure to appear at the trial, in spite of having been thrice summoned in the San Francesco church in Siena. However, according to the Inquisition's procedure, 'haereticus absens vel fugitivus' should be summoned once more so that he would hear the final sentence, which was passed one year after the last subpoena. ${ }^{24}$ In the case of Fausto Sozzini, however, the subpoena was not issued before 12 February 1590. A suspicion arises that the delay may have been a result of an imploring appeal extended by Fausto Sozzini to the Grand Duke Ferdinando de' Medici on 14 December 1588. Fausto complained in his letter about the cruelty and arbitrariness of inquisitors who force him - a man ailing and no longer young - to travel to Siena, where he would be tried for alleged crimes, moreover - for crimes committed in another country. Besides - wrote Sozzini - the Inquisition 'took possession of the few properties which remain under the authority of Your Highness'.$^{25}$ It cannot be excluded, however, that the delay in the trial had other reasons, that might be elucidated by a more thorough research in the archive of the Sienese Inquisition.

On 19 June 1590 the cause has been finally decided by the Roman congregation of the Holy Office: 'The most honourable and eminent lords Cardinals [...] decided the image of the said Fausto to be handed over to the secular arm, whereas his property - if possible - to be confiscated, and the profit from it to be given for the use of the house of the Inquisition and its archive in this city [that is, Siena]', ${ }^{26}$

24 Cf. C. Carena, Tractatus de Officio Sanctissimae Inquisitionis et modo procedendi in causis fidei, Cremona, 1668 [1st ed. - 1631], p. 307; E. Masini, Arsenale, overo prattica dell'Officio della Santa Inquisizione, Rome and Bologna, 1716, pp. 334-35.

25 A. Fabronius, Historia Academiae Pisanae, vol. 2, Pisa, 1792, pp. 118-20. It is noteworthy that the sentence of 1591 was sent to the Grand Duke Ferdinand. The Medici, although maintaining correct relationships with the Inquisition, always cared to control its activities.

26 ACDF, S.O., Decreta 1590-1591, 1. 225. 
The sentence in the case of Fausto Sozzini was passed in Siena, most probably late in September $1590,{ }^{27}$ but it was not announced publicly before February of the next year. The decision to confiscate the property of Fausto Sozzini triggered immediately a wave of protests and reservations on the part of the tenants of his lands, Orazio and his brother Rutilio Marsili (whose father Cornelio has already died), as well as - more importantly - Alessandro Sozzini (son of Fausto's uncle Celso), who appeared in the trial for the family. The dispute lasted at least to the end of the first decade of the seventeenth century. This, however, may be a subject for another discussion.

The sentence was ceremonially read out on 3 February 1591 in the San Francesco church in Siena, in the presence of the members of the tribunal and representatives of the Curia. Fausto Sozzini, who - as absentee appeared before the tribunal 'in statua', ${ }^{28}$ was sentenced to death. The justification of the sentence does not mention the anti-Church activity of Sozzini in Siena, but focuses on his manifold - literary, pastoral and teaching - activities in Poland, which were directed against the Catholic Church. The rather detailed presentation of Sozzini's anti-trinitarian doctrine was based not on a deeper knowledge of his works. Instead, the doctrine was discussed sub specie of the heresies of Arius and Paul of Samosata, according to classic ecclesiastical polemic scheme to regard everyone questioning the dogma of the Holy Trinity as an Arian, and everyone rejecting the preexistence of Christ as a follower of Paul of Samosata. There seems to be a contradiction in the general assessment of Sozzini's activity in Poland. On the one hand through his 'diabolic fervour' Sozzini earned a reputation of 'an angel and a great Tuscan theologian', but on the other hand his erroneous teachings were allegedly formulated 'with such a vagueness and ignorance that many members of your sect, being unable to comprehend your obscure and false opinions, have abandoned you and left'. Thus the Sozzini's 'subtlety', mentioned repeatedly during the trial, transformed into 'vagueness and ignorance' in the verdict.

27 ACDF, Siena, Processi, file 16, 1. 414-16.

28 On 19 January, the Inquisitor of Siena asked the Grand Duke the permission to hand over Sozzini's image to the secular arm and the governor of Siena inquired on the same day whether he should approve an execution in effigie (Marchetti, 'Do biografii...', op. cit., p. 162), while the sentence was ceremonially announced on 3 February. Thus it may be supposed that Fausto Sozzini's likeness was burnt shortly after. 
The main aim of the trial, which predictably concluded with the death sentence, was to deprive Sozzini of financial means needed to stay in Poland. ${ }^{29}$ The inquisitors in Siena were, however, completely uninterested in Polish followers of Sozzini or Poland as such - a 'distant country', which they knew only vaguely, as it appears from the trial's records. Aside from punishing the 'great Tuscan theologian', the inquisitors aimed for detecting his potential followers in Siena. It was not without a reason that numerous witnesses examined during the trial were scions of families bound together with the Sozzinis by long-standing friendship, many of them also sharing their religious beliefs. It is also noteworthy that the majority of witnesses were quite well informed on the 'Frastagliato's fate. They spoke of him with respect or even liking, and only when confronted with discontent or threats on the part of their interrogators, they forced themselves to reprove or condemn him (obviously, this does not concern the confessions of the papal diplomat Orazio Spanocchi). It would be interesting to know - and perhaps the records of the Inquisition in Siena enable us to find the answer to this question - whether the interest in the defiant family and its most eminent member lasted somehow also in next centuries.

\section{Translated by Kamil O. Kuraszkiewicz}

First published as: 'Proces Fausta Socyna w Sienie', Odrodzenie i Reformacja $w$ Polsce, 46, 2002, pp. 79-90.

29 In his letter dated 17 May 1586, Sozzini informed Bianca Capello about his marriage, but also expressed his wish to return to Italy: 'a finire secondo mio antico desiderio la mia vita nello stato del Granduca mio signore, poiché quivi sono et saranno sempre i miei pochi beni paterni et qui appena sono per haver mai nulla' (Florence, Archivio di Stato Mediceo, file 5946, 1. 645). 